\title{
DE LANGE LINJER I NORSK SPRÅKHISTORIE ETTER 1814 - NASJONAL OG SOSIAL SPRÅKSTRID OG SPRÅKPLANLEGGING
}

\author{
ERNST HÅKON JAHR
}

Svært mye er sagt og skrevet om og i språkstriden i Norge etter 1814, men $i$ alt dette er det egentlig likevel relativt lite av analyse, syntese og teoretisering. Mange hoved- og masteroppgaver er skrevet med emne fra norsk språkstrid, men de aller fleste er mer empirisk datainnsamling enn egentlig analyse og synteseutarbeiding.

Den språksituasjonen vi hadde i landet i 1814, da unionen med Danmark opphørte og Norge fikk sin egen grunnlov, var en ganske så normal situasjon språksosialt sett. Landet hadde et veldefinert skriftspråk, et høystatus talemål var tett knytta til dette skriftspråket, brukt av en relativt sett liten overklasse, mens resten av befolkninga, mer enn 95\%, brukte ulike lokale dialekter med lav sosial status. Det som i denne ganske normale språksosiale situasjonen likevel etter hvert skapte et problem, var at med 1814 og oppløsning av den dansk-norske unionen blei skriftspråket i Norge pr. definisjon et utenlandsk skriftspråk. Danmark var nå et annet land enn Norge, og dansk var derfor et utenlandsk mål, en annen nasjons språk. I tida med nasjonalromantiske strømninger måtte nettopp det gi opphav til bekymring, nemlig om den nye nasjonen egentlig kunne kalles en egen nasjon, når den altså ikke hadde sitt eget språk.

Det er viktig å stille spørsmål som gir fruktbare svar. Jeg vil begynne med et kanskje litt overraskende spørsmål her, men - som det forhåpentligvis vil vise seg - et som kan åpne opp for en forståelse av den grunnleggende forskjellen 
mellom de to viktigste programmene for ei norsk språkutvikling etter 1814 programmene til Ivar Aasen (1813-96) og Knud Knudsen (1812-95) - nemlig dette: Hvor gammelt er Norge?

Det å stille spørsmålet om Norges alder - som tilsynelatende ikke har noe med språk å gjøre - viser seg å hjelpe til med å forstå en prinsipielt viktig skilnad mellom Aasens og Knudsens programmer for norsk skriftspråksutvikling. For mange vil det spontane svaret på spørsmålet om Norges alder være at Norge er gammelt, og iallfall fra slaget ved Hafrsfjord rundt 900, da kong Harald Hårfagre skal ha samla Norge til ett rike. At Norge er gammelt, vil være Ivar Aasens svar også. I nasjonalromantikkens periode i første halvdel av 1800-tallet er derfor Norges storhetstid i middelalderen viktig. Dansketida blir en sørgelig periode i landets og nasjonens historie. Aasen ville i si samtid etablere en språklig forbindelse fra storhetstida tvers gjennom dansketida til nåtida. Han ville få dansketida til å framstå som en parentes i norsk historie. Derfor var han purist når det gjaldt dansk og tysk språkstoff som var kommet inn i norske dialekter i den 400-årige parentesen. Det greide han ved den ord-purismen han fra første stund praktiserte i skriftspråksframlegget sitt, Landsmålet.

På denne måten bandt Aasen den gammelnorske storhetstida sammen med Norge på 1800-tallet, gjennom språket. For å få til det, måtte han utelukkende bygge på bøndenes talemål, på bygdedialektene. Bonden var nasjonens redningsmann, sa han, til bonden burde vi derfor lytte. (Aasen [1836] 1909.) Og svaret på spørsmålet, det er altså at Norge er gammelt.

Helt annerledes da med Knud Knudsen! Som den rasjonelle praktiker han var, så han hen til det talespråket i landet som for Aasen symboliserte dansketida mer enn noe annet: embetsmennenes talespråk, som jeg vil omtale som talt riksmål. Knud Knudsen kalte det "den dannede Dagligtale" og "den landsgyldige norske Udtale”. (Knudsen 1876.) Dermed sier også Knudsen at han ikke legger noe vekt på linjene tilbake i historia til middelalderens storhetstid, ikke språklig, og ikke på annen måte heller. Knudsen var ingen nasjonalromantiker, og hans svar på spørsmålet om Norges alder er derfor: Norge er ungt, Norge blei født i 1814. Representanter for embetsmannsklassen stod i særlig grad bak frihetsverket det året. Deres talespråk, mente Knudsen, måtte derfor naturligvis kunne brukes som basis og grunnlag for landets skriftspråk. Dette talespråket var utvikla i Norge, det blei utelukkende talt i Norge, og ingen enkeltdialekt i landet hadde på langt nær så mange brukere. Dessuten var talt riksmål brukt over hele landet, og blei forstått av alle.

Det er naturligvis ikke bare Knud Knudsen som i teori og praksis regner med at Norge er en ung nasjon. Tyskeren Hans Magnus Enzensberger, for å nevne ett eksempel, gav i 1984 ut boka Norsk utakt, der han med sitt europeiske utgangspunkt beskrev og analyserte Norge og nordmennene. Mye av det særegne og 
eksotiske som Enzensberger trekker fram, forklares med at Norge er en ung nasjon i Europa, ennå ikke fullt 200 år.

Knudsen var som nevnt verken romantiker eller særlig opptatt av nasjonale spørsmål, men som Aasen var han språkpurist. Også han ville fremmed språkgods til livs, men ut fra et helt annet utgangspunkt - nemlig pedagogisk og med en helt annen konsekvens enn Aasen. Mens Aasen satte danske og tyske ord på index, men godtok ord av latinsk og gresk opphav, ville Knudsen ha bort også de sistnevnte, og han gav ut ei svær bok, Unorsk og norsk eller fremmedords avløsning (Knudsen, 1881), med mange konkrete forslag. Svært få av Knudsens forslag har likevel slått igjennom, og grunnen er kanskje at Knudsens purisme ikke var kopla naturlig til programmet hans for øvrig. Purismen hos Knudsen var på sett og vis unødvendig, mens den var helt essensiell for Aasens ideologi og program.

Av det jeg til nå har sagt, skulle det gå tydelig fram at sjølve jokeren her, er talt riksmål. Hele språkspørsmålet i Norge avgjøres i grunnen av hvordan talt riksmål oppfattes, hvordan det bestemmes som språktype.

Det å artsbestemme talt riksmål er fullt og helt et språkvitenskapelig spørsmål, og det var det også på Aasen og Knudsens tid. Men språkvitenskap da og språkvitenskap nå er naturligvis svært forskjellig, lingvistikken har utvikla seg vesentlig teoretisk siden første halvdel av 1800-tallet, da Aasen og Knudsen begynte sine arbeider.

La meg først si litt om hvordan vi ser på talt riksmål i dag, etter at den moderne språkkontaktforskninga - som er utvikla etter krigen - har gitt oss helt nye innsikter når det gjelder slike språkkontaktresultater, som talt riksmål er et eksempel på. Det viser seg da at denne språkvarianten er svært sjelden.

Talt riksmål er det vi med et begrep fra språkkontaktforskninga kaller et kreoloidspråk. Et annet språk av samme art er afrikaans i Sør-Afrika. Afrikaans har nederlandsk som utgangspunkt, og er et resultat av kontakt mellom nederlandsk og innfødte sørafrikanske språk, men det har aldri helt tapt forbindelsen til opphavsspråket, og det har alltid, så langt vi kan følge språkets historie bakover, vært morsmål for sine brukere. Språkkontakten har imidlertid medført betydelige grammatiske forenklinger både $\mathrm{i}$ forhold til utgangsspråket nederlandsk og i forhold til de innfødte språka.

Talt riksmål er et resultat av kontakt på 1600- og 1700-tallet mellom skriftlig dansk og muntlig norsk. Det har alltid vært morsmål for sine brukere, og det har aldri tapt forbindelsen til dansk. Samtidig oppviser talt riksmål en rekke grammatiske forenklinger både $\mathrm{i}$ forhold til dansk og til norske dialekter, og er således en god parallell til afrikaans, som i internasjonal litteratur er sjølve prototypen på et kreoloidspråk (jf. Trudgill, 1986). Jeg har her ikke tid til å komme inn på de mange nye problemstillingene vi kan utforske på grunnlag av denne artsbestemmelsen av talt riksmål, men de er både mange og interessante. I dag er 
problemstillinga fra 1800-tallet, om talt riksmål er norsk eller dansk, fullstendig uinteressant fra et språkvitenskapelig synspunkt, men denne problemstillinga blei i nordistikken hos oss uheldigvis trukket unødig langt inn på 1900-tallet.

Det er et viktig poeng at Ivar Aasen var fullstendig på høyde med og i forskningsfronten i språkvitenskapen i si tid. Han brukte den såkalte historiskkomparative lingvistikken på en innovativ måte da han utvikla landsmålet. Men for Aasen var det umulig med datidas teori å gi en nærmere analyse og karakteristikk av talt riksmål. Språkvitenskapen, slik den stod til rådighet for han, hadde ingen begreper og ingen teori om språkkontaktresultater, bortsett da fra konkrete lån mellom ulike språk, særlig lånord. Men at språkkontakt kunne skape helt nye språk og språkvarianter, var det ikke mulig for språkviterne på Aasens tid å forklare.

Derfor var han isteden henvist til å stille det skjebnesvangre spørsmålet, det som i grunnen hele språkstriden i Norge hviler på: Er talt riksmål norsk eller dansk? Aasens svar var at det i hovedsak var dansk, og ingen kan egentlig kritisere han for det, gitt datidas språkvitenskap. Aasen hadde altså rett $i$ si tid, kan vi si.

Knud Knudsen derimot baserte seg ikke på noen samtidig språkteori eller metode. Knudsen ikke kunne forankre sitt program i samtidas språkvitenskap, slik Aasen kunne, og gjorde. Knudsen var en praktiker, en pragmatiker som søkte løsninger han syntes var fornuftige og til alles beste, som den pedagogen han var. Knudsen var utdanna filolog fra universitetet, og tjente $i$ alle år som overlærer ved Oslo katedralskole. Slik Knudsen tenkte om språkutviklinga, slapp han helt å ta stilling til spørsmålet om talt riksmål var norsk eller dansk, dvs. han tok for gitt at det var norsk godt nok. Dermed var han i samtida klart utafor en vitenskapelig basert analyse og vurdering.

Det var også grunnen til at P.A. Munch, som roste Aasens arbeider opp i skyene, vendte seg med hele sin autoritet mot Knud Knudsens tanker, og kritiserte dem sønder og sammen. Munch hadde god forstand på samtidas forskningsfront innen språkvitenskapen. Og mens han holdt fram Ivar Aasen som et geni, brukte han ganske nedsettende ord om Knudsen. Knud Knudsen skreiv seinere at han aldri helt greide å komme ut av den tåka som P.A. Munch med dette hadde lagt over han og språkprogrammet hans.

Det burde være åpenbart for alle at det $\mathrm{i}$ de to programmene, Aasens og Knudsens, lå godt til rette for ikke bare en prinsipielt ulik språkplanleggingsstrategi, to ulike måter å utvikla et norsk skriftspråk på, men at det sammenvevd i dette måtte bli ei djup kulturell og politisk motsetning.

Den språksosiale forskjellen mellom Knudsens program og Aasens program var tydelig nok, og gav rikelige muligheter for den politiske opposisjonen fram mot 1884 til å bruke Aasens program for alt den var verdt. 1884 var som kjent året da embetsmannsstaten falt, og parlamentarismen blei innført. Venstre leda 
an i denne utviklinga, og Aasens program var en integrert del av partiets program. Allerede året etter, i 1885, kom det såkalte ,jamstillingsvedtaket“ i Stortinget. Etter det har vi hatt to formelt likestilte målformer i Norge. Det var som følge av den truende språkrevolusjonen representert ved landsmålet, at Knudsen nå langsomt fikk rett, om han enn ikke hadde hatt det før, hvis vi skal bedømme det etter språkvitenskapen på 1800-tallet.

Ved språkreformene i 1907 og 1917 blei det danske skriftspråket i Norge gjort om til norsk riksmål (fra 1929 kalt bokmål) ved at ord og former blei endra slik at de nesten helt ut avspeilte talt riksmål. Knud Knudsen hadde fått rett.

På 1920-tallet utvikla språkvitenskapen seg raskt både internasjonalt og her hjemme. Hos oss var det Alf Sommerfelt som særlig stod for de nye retningene i lingvistikken, da han i 1920 vendte tilbake til Norge etter lange studier og forskning i Frankrike. I Videnskabsselskabet i Kristiania (nå: Det Norske Videnskaps-Akademi) støtte han veldig sammen med tyskprofessoren Hjalmar Falk, som forsvarte de språkvitenskapelige teoriene fra 1800-tallet, de som fortsatt dominerte norsk språkvitenskap, og som derfor fortsatt stengte for en mer fruktbar beskrivelse f.eks. av talt riksmål. I nordisk språkvitenskap (i Norge) fortsatte paradigmet fra 1800-tallet til langt ut på 1970-tallet (Jahr, 1996; 2011). Med Alf Sommerfelt, som blei en av verdens aller første professorer i allmenn språkvitenskap i 1931, kom derfor et viktig skisma inn i norsk språkvitenskap.

Mens nordisk språkvitenskap holdt på det eldre paradigmet fra 1800-tallet, blei nye teorier og metoder introdusert gjennom allmennlingvistene, og med Sommerfelt i spissen. Når nordisk språkvitenskap slik holdt fast på sitt tradisjonelle teoriparadigme, den såkalte junggrammatikken, så lenge, så var nok det iallfall delvis faglig begrunna $i$ at kunnskapstilfanget, innsamlinga av empiri fra dialektene, talte for å fortsette som før, for ikke å kaste vrak på de innsamlingene som var gjort gjennom så mange år. Men når det samme paradigmet så lenge tilsa at forskere innen nordisk språkvitenskap egentlig ikke burde arbeide med beskrivelse av talt riksmål, fordi det pr. definisjon falt utafor forskningsobjektet norsk språk, har jeg tidligere tillatt meg å kalle det for et misbruk av språkvitenskapen. (Jahr, 2007.)

Resultatet av denne totale utdefineringa av talt riksmål fra forskningsobjektet til nordistikken i Norge var dermed at språkforskere fra andre særspråk enn norsk kom til å stå for de grunnleggende beskrivelsene av talt riksmål, paradoksalt nok. Språkforskere som gav viktige bidrag til beskrivelse av talt riksmål, var bl.a. engelskfilologen August Western, tyskfilologen Clara Holst, keltologene Alf Sommerfelt og Carl Hjalmar Borgstrøm, og romanisten Hans Vogt.

Beskrivelsene som disse framstående språkforskerne gav av talt riksmål var langt mer prega av nyere lingvistiske teorier enn beskrivelsene av norske dialekter som samtidig blei gjort i nordisk språkvitenskap. Teori- og 
metodeutprøving innen språkvitenskap i Norge har således primært hatt andre språk enn norsk som beskrivelsesobjekt, og, av språkvarianter i Norge, talt riksmål, mens det junggrammatiske teoriparadigmet fortsatte å dominere innen nordistikken. (Jahr, 1996; 2011.)

Ikke bare talt riksmål, også skriftspråket bokmålet er i internasjonal sammenheng ganske spesielt, noe Aasens nynorsk til sammenlikning ikke er. Ikke noe nasjonalspråk vi kjenner, er blitt til på samme måte som bokmål i Norge.

Det eneste europeiske landet som har hatt en språkutvikling med konkurranse mellom to skriftformer av samme språk, er, ved sida av Norge, Hellas. Men verken dimotiki (som betyr ,folkemål"), eller katharevousa (som betyr "reint språk", jf. katharsis, renselse) kan historisk sammenliknes med bokmål - som er blitt til norsk gjennom en gradvis fornorskning fra et reint dansk utgangspunkt. Dimotiki kan nok i mye likne på nynorsk, mens katharevousa likevel vanskelig kan sies å være en parallell til bokmål. Hvis en vil, kan en lett finne nynorskparalleller også i katharevousa, og bokmålsparalleller i dimotiki. I Hellas er det nå slik at dimotiki har vunnet en endelig seier. Det skjedde etter at oberstjuntaen, som styrte mellom 1967 og 1974, innførte katharevousa overalt som påbudt målform. Med juntaen forsvant nesten all støtte til katharevousa. Svært få ville ha noe mer med den målforma å gjøre. Hellas har dermed gått en annen veg enn oss. Mens Stortinget i 2002 slo fast en permanent to-skriftspråkssituasjon, noe jeg vil komme tilbake til om litt, har den ene målforma i Hellas utkonkurrert den andre. (Jahr and Trudgill, 1993.)

Hellas var den eneste egentlige parallellen vi hadde til Norge når det gjaldt å ha to målformer av samme nasjonalspråk, men nå er Norge helt aleine på akkurat den arenaen. Vi kan da gjøre disse to viktige observasjonene om norsk språk og språkbruk, som gjør at Norge skiller seg vesentlig ut fra alle andre europeiske språksamfunn i dag:

1. Norge har to formelt likestilte norske skriftspråk. I andre land med to eller flere skriftspråk, som Belgia og Sveits, er det snakk om helt ulike og gjensidig ikke-forståelige språk. La meg nevne en passant at Belgia har en språklov som slår fast at landet har to likestilte språk, fransk og nederlandsk (eller flamsk, som de sier i Belgia), men at det ikke er lov å foreta tellinger av hvor mange det er som bruker hvert språk. Antallet språkbrukere skal nemlig ikke kunne brukes til å svekke de språklige rettighetene til dem som bruker minoritetsspråket.

2. I Norge er det en bestemmelse i skolelova som forbyr læreren å korrigere elevenes talespråk. Mange vil vite at dette går tilbake til et vedtak i Odelstinget så tidlig som 1878, men det var mellom 1904 og 1924 til tider skarp strid om dette prinsippet. Det var vanskelig for mange å akseptere at lærerne ikke skulle kunne veilede elevene i muntlig språkbruk på samme måte som på alle andre områder. Om det store flertallet av lærere ikke har retta på talespråket til elevene 
sine, er det likevel fortalt nok av historier fra elever som blei retta på i klasserommet av lærere som i beste mening ønska at elevene skulle snakke mer „korrekt" eller ,penere“, slik læreren så det. At dette er skjedd i langt mindre grad i Norge enn i andre land, er det likevel ingen tvil om, og dessuten har det aldri vært en del av lærestoffet i skolen at elevene skulle tilegne seg et standardisert talespråk. Det har vært effektivt forhindra av bestemmelsen i skolelova om elevenes rett til fritt å kunne benytte sitt eget talespråk. Det er videre opplagt at dette prinsippet har hatt stor betydning for at Norge framstår som det mest dialekttalende landet i Europa i dag. (Jahr, 1984.)

Da Stortinget i 2002 gjorde et enstemmig vedtak om å legge samnorskpolitikken til side, trakk tydeligvis mange et lettelsens sukk, både bokmålsfolk og nynorskbrukere. Det planmessige arbeidet for å komme fram til bare én skriftspråksstandard i Norge, hadde ikke ført fram, og nå tok Stortinget konsekvensen av det, slik de fleste tolka det.

Det er imidlertid mulig å se på dette på en noe annen måte. På 1800-tallet var hovedmålet for mange at Norge skulle ha sitt eget skriftspråk, atskilt og forskjellig fra dansk og svensk. Vi har sett at Aasen og Knudsen hadde hvert sitt program for dette, og vi vet at de begge gav som resultat en norsk skriftnormal. Tidlig på 1900-tallet var det klart for alle som ville se, at vi fått - ikke ett, men to norske skriftspråk.

Det var få, om noen, som den gangen så for seg at dette skulle bli en permanent situasjon, med to så like skriftnormaler. Folk som var opptatt av dette spørsmålet, så enten for seg at et av de to skriftspråka ville utkonkurrere det andre fullstendig, eller - og dét var det nye tidlig på 1900-tallet - så så en for seg en minnelig løsning, en løsning som tok opp i seg begge de konkurrerende skriftnormalene, både den etter Ivar Aasen og den etter Knud Knudsen.

Samnorskpolitikken, som dette etter hvert blei kalt, slo gjennom i Stortinget rundt 1915, og var et hovedsiktemål i offisiell språkplanlegging fram til 1964. Noen vil nok mene at samnorskpolitikken varte enda lenger, men egentlig var den slutt da, med at Gerhardsen-regjeringa nedsatte den såkalte språkfredskomiteen etter hemmelige forhandlinger med representanter for riksmålsbevegelsen. Språkfredskomiteen blei også kalt Vogt-komiteen, etter rektor og professor Hans Vogt ved Universitetet i Oslo, som blei utpekt til å lede komitearbeidet. Etter at denne komiteen la fram si tilråding i 1966, fikk vi en svært lang avviklingsperiode. Først i 2002 satte altså Stortinget et endelig punktum.

Så sier da alle at samnorskpolitikken var helt mislykka. Ja, mon det? Utgangspunktet for denne språkpolitikken var ønsket om å bevare begge språktradisjonene uten at noen av dem tapte for den andre. Samtidig var det et utbredt syn at et fattig land som Norge ikke kunne holde oppe to så like skriftnormaler. Det ville ikke være økonomisk mulig. På 100 år har dette skifta dramatisk. I dag har vi uten tvil råd til å holde oss med to skriftnormaler, og det har 
gjennom de siste generasjonene også vært et voksende syn at uten begge tradisjonene, bokmålstradisjonen og nynorsktradisjonen, vil nasjonen lide et stort kulturtap, som egentlig ingen ønsker å være ansvarlige for. Derfor trenger vi politisk ikke samnorskpolitikken lenger, og vi har råd til å la være.

Samnorskpolitikken, som kom som et svar på et konkret problem i det norske samfunnet tidlig på 1900-tallet, er ikke lenger nødvendig. Problemet, slik en så det den gangen, er forsvunnet, og det som samnorskpolitikken var tenkt å redde, nemlig kulturverdien i begge skriftnormalene, har vi fortsatt. Slik sett har derfor heller ikke den opprinnelige samnorskpolitikken tapt.

For seg sjøl står imidlertid samnorskpolitikken mellom 1917 og 1964. Den presenterer oss for et unikt språksosialt eksperiment, som ikke er forsøkt noe annet sted verken før eller siden. Vi kunne også kalle det et sosialistisk eksperiment på det språklige området. Det som blei forsøkt, var å forandre hele den språksosiale situasjonen i landet gjennom en politisk vedtatt språkplanleggingsvirksomhet.

Fram til 1917 gikk hovedmotsetninga i språkdebatten på det nasjonale, særlig hva som skulle gjelde for norsk i språklig sammenheng, dvs. hva som var dansk og hva som var norsk, og hvordan vi skulle utvikle et eget skriftspråk, ulikt dansk og svensk. Med reforma i 1917 hadde vi utvilsomt utvikla to norske skriftspråk. Knud Knudsens program med fornorsking med basis i den dannede dagligtale, talt riksmål, var fullført. Med 1917-reforma var det også slik at skriftlig riksmål/bokmål kunne skrives helt ut som et speilbilde av talt riksmål. I tillegg hadde imidlertid myndighetene, og med stortingsflertallets klare støtte, begynt et arbeid med å forberede et framtidig samnorsk skriftspråk. I riksmål gjaldt det de radikale såkalte «valgfrie» formene, som i åra som fulgte umiddelbart etter 1917, førte til en intensitet i språkstriden som vi aldri hadde hatt tidligere, og som vi aldri har sett seinere.

Selv om en del også etter 1917 fortsatte å snakke om norsk og dansk i språkstriden, og særlig var dette fortsatt ansett som gyldig argument på nynorsksida, så var åpenbart den tida forbi da i hovedsak nasjonale argument kunne drive skriftspråksutviklinga videre. Den som så det klarere enn de fleste, var professor Halvdan Koht. Skulle en komme videre på den utviklinga som stortingsflertallet nå ønska, nemlig mot et fellesnorsk samla skriftspråk, måtte det utvikles en ny analyse og språkplanleggingsstrategi. (Koht, 1921.)

Det prinsipielt nye var at hovedvekta blei lagt på det språksosiale, ikke det nasjonale. Ikke norsk først og fremst, men vanlige folks talespråk, by- og bygdedialektene i motsetning til talt riksmål som norm og ideal for skriftspråket. Det blei hevda at det var arbeiderbevegelsens historiske oppgave å løse språkspørsmålet i Norge, og det skulle gjøres til fordel for de såkalte breie folkemasser, på samme måte som arbeiderbevegelsen også arbeida for arbeidernes, bøndenes og 
fiskernes økonomiske og kulturelle interesser. Visjonen her var at vanlige folks talemål skulle få økt sosial status. Det fulgte av dette at taperen måtte bli talt riksmål og dets brukere, $\mathrm{i}$ og med at denne politikken ville definere talt riksmål ned som grunnleggende norm for bokmål.

Det politikerne da så for seg som et endelig resultat, var ett samnorsk skriftspråk bygd på folkemålet $\mathrm{i}$ by og bygd. Dette skriftspråket ville i sin tur gi $ø \mathrm{kt}$ sosial status til det samme folkemålet, noe som ville bety økt bruk av bygdeog bydialektene overalt i samfunnet og uansett kontekst. Status og privilegier skulle overføres fra brukerne av talt riksmål til brukerne av folkemålet, til dialektbrukerne i bygd og by. Igjen skulle altså talt riksmål defineres ut, men ikke fordi det var dansk, som var Ivar Aasen argument, men fordi det representerte overklassens språkform muntlig.

En mer radikal språkpolitikk, eller et mer vidtgående språksosialt eksperiment, er neppe foreslått noe annet sted. (Jahr, 2014.) I en slik kontekst og forståelse er det også lettere å innse hva rettskrivningsreforma i 1938 representerer. Det som stod klart for de ivrigste riksmålsforkjemperne, og som var helt riktig, var at reforma var et seriøst angrep på status og posisjon til talt riksmål. Riksmålsbevegelsen vendte seg derfor raskt mot det de hevda var „ødeleggelsen av vårt sprog“". Men riksmålsfolk var, forståelig nok får vi si, lite opptatt av den andre sida av reforma, som gikk ut på å heve statusen til andre talemål over hele landet, og særlig til dialektene på Østlandet, i Trøndelag, i Nord-Norge og i byene, ved å gjøre ord og former fra disse lavstatus talemåla ikke bare valgfrie i bokmål, men ofte påbudte. Dermed gav offisielt bokmål beskjed om at mange ordformer i talt riksmål ikke lenger var å anse som korrekte former i skriftspråket.

Slik var 1938-reforma langt på veg en konsekvent oppfølging av Arbeiderpartiets analyse og politikk på det språklige området, slik det var utarbeida særlig på 1920-tallet. Reaksjonen fra riksmålsbevegelsen er også fullt ut forståelig.

Ingen liker å miste hevdvunne privilegier. Det gjelder i høy grad også på det språklige området. Språkstriden som fulgte på 1950-tallet gjaldt først og fremst bokmålet. Den politikken som lå bak 1938-reforma, tapte. En av hovedgrunnene til det var at det ikke var tilstrekkelig støtte bak det ytterst radikale språksosiale eksperimentet som 1938-reforma representerte. Skulle det ha lyktes, måtte Arbeiderpartiet ha vært langt mer konsolidert på denne politikken, den måtte ha blitt støtta av en folkelig bevegelse, og den måtte ha blitt fulgt opp av flere nye reformer. Disse nødvendige forutsetningene var overhodet ikke til stede på 1950-tallet, og dermed var utfallet egentlig gitt.

At det så tok mange år før Stortinget i 2002 til slutt vedtok å gravlegge samnorskpolitikken, hadde mange årsaker. Den viktigste er kanskje at det for mange språkpolitikere, og også for Stortinget, tross alt har vært vanskelig å gi slipp på 
tanken om at det likevel må være en fordel om vi til slutt kunne nå fram til bare én skriftnormal for norsk skriftspråk. Først da det var åpenbart for alle at når vi nå har hatt to offisielle skriftnormaler i godt over 100 år, kan vi faktisk fortsette å ha det, både fordi de begge representerer viktige kulturelle verdier vi nødig vil miste, og fordi Norge nå er økonomisk i en helt annen situasjon enn vi var den gang Norge var et av Europas fattigste land.

Det er interessant å merke seg at i 2002 innførte Stortinget noe prinsipielt helt nytt $\mathrm{i}$ den norske språksituasjonen - antakeligvis uten at stortingsrepresentantene var helt klar over det. Fra Ivar Aasen og Knud Knudsens tid og helt fram til 2002 hadde språkpolitikken - på ulike måter - hele tida hatt for øye at vi skulle ende opp med bare én skriftnormal. Stortingets samnorskpolitikk var naturligvis helt entydig slik, men også før samnorskpolitikken var tanken at enten skulle vi ende opp med bare landsmål/nynorsk, eller bare riksmål/bokmål. Fra og med 2002 er det imidlertid for første gang slått fast som offisiell politikk at vi skal fortsette å ha to norske skriftnormaler i overskuelig framtid.

Denne overgangen i 2002 fra en konsekvent én-standardstrategi i språkplanlegginga til en to-standardstrategi er det viktigste språkpolitiske vedtaket Stortinget har gjort på flere tiår. Så får framtida vise om eller hvor lenge denne to-standardstrategien holder seg.

\section{Litteraturliste}

Aasen, I. [1836] 1909. Om vort Skriftsprog. Syn og Segn 17. 1-5.

Enzensberger, H.M. 1984. Norsk utakt. Oslo: Universitetsforlaget.

Jahr, E.H. 1984. Talemålet $i$ skolen. En studie av drøftinger og bestemmelser om muntlig språkbruk i folkeskolen (fra 1974 til 1925). Oslo: Novus.

Jahr, E.H. 1989. Utsyn over norsk språkhistorie etter 1814. 2. reviderte utgave 1994. Oslo: Novus.

Jahr, E.H. 1996. «Nynorsk språkforskning - en historisk oversikt». I: Henriksen, C., Hovdhaugen, E., Karlsson, F. og B. Sigurd. (red.). Studies in the development of linguistics in Denmark, Finland, Iceland, Norway and Sweden. Papers from a conference on the history of linguistics in the Nordic countries, Oslo, November 20-22, 1994. Oslo: Novus. 84-101. Opptrykt i Wiggen, Geirr, T. Bull og M. Aamodt Nielsen (red.): Språkhistorie og språkkontakt. Language history and language contact. Festskrift til Ernst Håkon Jahr på 60-årsdagen 4. mars 2008. Oslo 2008: Novus. 196-209.

Jahr, E.H. 2007. "The (mis)use of linguistics: linguistic research and Norwegian nation building". I: Elmevik, L. (red.). Nya perspektiv inom nordisk språkhistoria. Föredrag hållna vid ett symposium i Uppsala 20-22 januari 2006 (Acta Academiae Regiae Gustavi Adolphi 97). Uppsala: Swedish Science Press. 81-88.

Jahr, E.H. 2011. "Dialektologi som nasjonsbygging. Til diskusjonen om 'nynorsk språkforskning"”. I: Edlund, L.-E., Elmevik, L. og Reinhammar, M. (red.). Studier i dialektologi och sociolingvistik. Föredrag vid Nionde nordiska dialektologkonferensen $i$ Uppsala 18-20 augusti 2010 (Acta Academiae Regiae Gustavi Adolphi 116). Uppsala: Swedish Science Press. 159-167. 
Jahr, E.H. 2014. Language planning as a sociolinguistic experiment: the case of modern Norwegian. Edinburgh: Edinburgh University Press.

Jahr, E.H. and P. Trudgill. 1993. "Parallels and differences in the linguistic development of Modern Greece and Modern Norway". I: Jahr, E.H. (red.). Language conflict and language planning (Trends in Linguistics, Studies and Monographs 72). Berlin/New York: Mouton de Gruyter. 83-98.

Koht, H. 1921. Arbeidarreising og målspørsmål. Kristiania: Det Norske Arbeiderpartis Forlag.

Knudsen, K. 1876. Den landsgyldige norske Udtale. Kristiania: A.W. Brøgger.

Knudsen, K. 1881. Unorsk og norsk eller fremmedords avløsning. Kristiania: Alb. Cammermeyer.

Knudsen, K. 1887. Kortfattet redegjørelse for det dansknorske målstrcev. Kristiania: Chr.H. Knudsen.

Trudgill, P. 1986. Dialects in contact. Oxford: Blackwell. 